\title{
A Study on The First-Language Influence on The Arabic Pronunciation among Terengganuians in Malaysia
}

\author{
Ahmad Zulfadhli Nokman (Corresponding author) \\ Akademi Pengajian Bahasa, Universiti Teknologi MARA, Terengganu, Malaysia \\ 23000 Dungun, Terengganu, Malaysia \\ E-mail: zulfadhli@tganu.uitm.edu.my \\ Azman Che Mat \\ Akademi Pengajian Bahasa, Universiti Teknologi MARA, Terengganu, Malaysia \\ 23000 Dungun, Terengganu, Malaysia \\ E-mail: azman531@tganu.uitm.edu.my \\ Ahmad Fakrulazizi Abu Bakar \\ Akademi Pengajian Bahasa, Universiti Teknologi MARA, Terengganu, Malaysia \\ 21080 Kuala Terengganu, Terengganu, Malaysia \\ E-mail: ahmad1183@tganu.uitm.edu.my \\ Nor Shaifura Musilehat \\ Akademi Pengajian Bahasa, Universiti Teknologi MARA, Terengganu, Malaysia \\ 21080 Kuala Terengganu, Terengganu, Malaysia \\ E-mail: shaifura@tganu.uitm.edu.my \\ Ahmad Nazuki@Marzuki Yaakub \\ Akademi Pengajian Bahasa, Universiti Teknologi MARA, Terengganu, Malaysia \\ 23000 Dungun, Terengganu, Malaysia \\ E-mail: ahmadnaz@tganu.uitm.edu.my
}

Received: 21-12-2016

Published: 01-07-2017
Accepted: 05-02-2017

doi:10.7575/aiac.ijalel.v.6n.4p.76
Advance Access Published: April 2017

URL: http://dx.doi.org/10.7575/aiac.ijalel.v.6n.4p.76

\begin{abstract}
This study focuses on exploring the influences of the first-language influence on the Arabic pronunciation among Terengganuian learners. The study has involved five students, who were born in Terengganu, who communicate using the Terengganuian dialect. The students were asked to read some Arabic sentences while the researcher recorded their voices. Then, their pronunciations were transcribed and analysed. The findings showed that the influences of the Terengganuian dialect on the Arabic pronunciation actually exist. The respondents showed their habits unintentionally in pronouncing the sound $/ \mathrm{y} /$ while uttering such Arabic words which have been spelt with the letter ' $n$ '. This phenomenon is very familiar among Terengganuian people in terms of their local dialect.
\end{abstract}

Keywords: Influence, Arabic pronunciation, Terengganu dialect

\section{Introduction}

\subsection{Introduction}

Learning the Arabic Language in Malaysia is increasingly widespread among students either in schools or universities especially Malay students. That is because some languages, such as English, French, and Arabic, have become second languages in many communities of the world (S.O. Labo-Popoola, 2010), including Malaysians. However, there are many obstacles are faced by Malaysians to learn the Arabic Language. As a result, they are unable to master the target language as it should be especially in oral conversation.

Ashinida Aladin (2012) stated that the reasons that led to the weakness of Arabic language among students' verbal skills is because they are often unable to utter a word or make grammatical sentences correctly and say what they want to mean to their listeners. This is due to the differences between the language organ pronunciation in Arabic and Malay 
(Kamarulzaman and Rahimi, 2000). Furthermore, Malay language has many dialects in their respective states. This adds further distress to learn the pronunciation of Arabic dialects as the Malay language in Malaysia has its own unique attributes.

One of the main dialects in Malaysia is the Terengganuian dialect. In this study, the researchers were motivated to seek the influence of the Terengganuian dialect pronunciation in the Arabic pronunciation. According to the researchers' personal experiences and study, Terengganuian dialect is known for adding the letter 'ng' for words ending with the letter ' $n$ ', such as the word 'makan' (eat) is pronounced as 'makang' (Noor Rohana Mansor, Noraien Mansor, and Normaliza Abd Rahim, 2013). In addition, the letter ' $r$ ' is not pronounced like the vibration of the word 'mari' (come), but is pronounced as 'maghi'. This notion affects students in pronouncing the Arabic words.

\subsection{Problem Statement}

Today, many have realised the importance of learning the Arabic language, particularly among adults. They learn Arabic for a variety of purposes. However, the difficulty to pronounce Arabic words correctly made it difficult for them to master the language especially those who are tied to their respective states' dialects such as Terengganu, Kelantan, Penang, Kedah, and others.

So, is it true that the local dialects used by students is said to be the cause of the difficulty in pronouncing certain letters or vocabulary in Arabic? To prove this assumption, a study should be conducted to get an initial overview of Arabic language learning, especially in terms of pronunciation.

\subsection{Research Questions}

There are two main issues that can be addressed in this study, namely: 1- What are the Arabic pronunciations that are affected by the mother tongue?

2- Is Arabic pronunciation influenced by Terengganuian dialect pronunciation?

\subsection{Research Objectives}

The main objectives of this study are to:

1. Examine the influences in terms of students' native language towards Arabic pronunciation

2. Identify the Terengganuian dialect pronunciation in Arabic pronunciation

\subsection{Research Interests}

This study is important to provide useful information to help the difficult change in learning Arabic. From the aspect of learning strategy, students can devote more attention to the problem once they practise it effectively.

\section{Literature Review}

Past research shows that a speaker's mother tongue or first language influences the second language acquisition. Suthanthiradevi A / P J.N.J. Money (1996) in his citation noted that Ringbow (1976) conducted a study on a group of Swedish students about the effects of their first language on learning a second language which is English Language. As a result, she found that there was transference of the first language in the second language for the students.

Abdul Hamid Ahmad (1988) has listed several vocabulary errors of the Malay language among primary school students caused by the influence of the first language. For instance, the word 'besar' was spelt as 'busar'. This occurs due to the influence of the native Malay language.

In terms of Arabic language learning, Kamarulzaman Abd. Ghani and Nik Mohd Rahimi (2000) stated that the problem of wrong pronunciation of the letters in Arabic language among Malay students is common. This happens because there is a difference in consonants between Malay and Arabic. They explained in detail about the differences. There are differences between Malay language and Arabic language from the nature of the letter. The effect of the mother tongue or first language in Arabic pronunciation is among the factors that influences the Arabic pronunciation. This is because mastering pronunciation skills involves physiological factors, such as the organ, which is influenced by the first language uttered since childhood (Nik Mohd Rahimi et al., 2010).

In a study of Arabic consonant pronunciation proficiency among school children, Nik Mohd Rahimi, et al. (2010) suggested that the easy consonants of the Arabic language should be firstly introduced to the students before the difficult letters are taught. This shows that Arabic consonants need to be studied better. However, for university students, their learning ability of a second language is not the same as children who learn a second language. As a result, university students' second language is more influenced by their first language, especially in terms of a letter or word.

Regarding this subject, Azman Che Mat and Ahmad Nazuki Yaakob (2010) have found that university students who learned Arabic can remember the words learned by copying or writing with transliteration rules. Students also believed that the method of transliteration assisted them in communication skills. Accordingly, the use of transliteration can be used as a strategy to help adult learners master the Arabic pronunciation.

In conclusion, the influence of the mother tongue or first language in second language learning does exist among students who learn a second language. However, the level of Arabic language proficiency among them is what sets them apart from each other. 


\section{Methodology}

This study was conducted qualitatively. It uses methods of observation on five university students. The students are from Terengganu state but they have different backgrounds in learning the Arabic Language.

The first student learned Arabic from matriculation and then had spent time learning Arabic in two stages during two semesters. Meanwhile, the second student also had the experience of studying Arabic in high school until university. The third, fourth, and fifth students are currently learning Arabic in their third semester at their university and they did not have experience in learning Arabic language before that.

Observations on the reading of Arabic texts that were given to these students had been recorded and were given a code. Arabic text has been selected according to certain characteristics, namely text or excerpts of Arabic words that have been borrowed by the Malay language and adopted as Malay words.

Meanwhile, the transcriptions of respondents' pronunciation are taken from a text book known as "Al-Munir", which is published by Universiti Teknologi Mara, Malaysia (refer to Appendix). Finally, the transcriptions were analysed and compared with the correct pronunciations which is referred to Abdul Qadir Leong's (2003) teaching.

\section{Findings and Discussion}

\subsection{Findings}

After observing the respondents, there are several aspects that contribute towards the results. The analysis was carried out and the results are as follows:

Table 1. Transcription of Respondent 1's pronunciation

\begin{tabular}{|c|c|c|c|}
\hline Bil & Words & Transliteration & Respondent 1 \\
\hline 1 & قُقُبُوْرِ & qubūri & kubri \\
\hline 2 & مَحْظُوْرِ & mahzūrin & mahzurin \\
\hline 3 & الصنَّلَةٍِ & ass-salāti & as-salat \\
\hline 4 & عَوْرَةٌ & 'auratun & 'aurat \\
\hline 5 & رِجَالٍ & rijālin & rijālin \\
\hline 6 & مُنَتَقِّلَ & mutanaqqilan & mutanaqqalan \\
\hline
\end{tabular}

Table 1 shows the Arabic words that have been pronounced wrongly by Respondent 1. The words 'qubūri', 'as -salāti' and 'auratun' are words that have been used by Malays in terms of their pronunciation. That is why the respondent has pronounced the words as Malay words. Meanwhile, several alphabets in Arabic are not applicable in Malay pronunciations. For examples, letter ' $\tau$ ' is pronounced as 'ha', not 'ha'. This is the difference between Arabic and Malay pronunciation.

Table 2. Transcription of Respondent 2's pronunciation

\begin{tabular}{|c|c|c|c|}
\hline Bil & Words & Transliteration & Respondent 2 \\
\hline 1 & قَفُبُوْرِ & qubūri & Kubūri \\
\hline 2 & مَحْظُوْرِ & mahzūrin & mahzūring \\
\hline 3 & الصَّلَاةِ & as-salāti & aś-salāti \\
\hline 4 & عَوْرَةُ & 'auratun & 'auratun \\
\hline 5 & رِجَالٍٍ & rijālin & Rijālin \\
\hline 6 & مُنَنَقِقِلَ & mutanaqqilan & mutanaqqilan \\
\hline
\end{tabular}

Table 2 shows that the Respondent 2 pronounced Arabic words better than other respondents. This is due to a longer experience in learning Arabic. However, there are also several mistakes of pronunciation by this respondent. The main mistake is the pronunciation of the word 'mahzūrin'. The respondent has pronounced it as 'mahzüring', which is by adding the letter ' $g$ ' at the back. This is due to the influence of the Terengganuian dialect because Terengganuians always add the letter ' $g$ ' at the back of a word that ends with the letter ' $n$ '.

Table 3. Transcription of Respondent 3's pronunciation

\begin{tabular}{|c|c|c|c|}
\hline Bil & Words & Transliteration & Respondent 3 \\
\hline 1 & لَفُبُوْْرِ & qubūri & Kubūri \\
\hline 2 & مَحْظُوْرٍ & mahzūrin & Mahzūring \\
\hline 3 & الصنَّلَةِة & as $\underline{\text { salalāti }}$ & as-s $\underline{\text { salāh }}$ \\
\hline 4 & عَوْرَةُ & 'auratun & 'auratun \\
\hline 5 & رِجَالٍ & rijālin & Rijāling \\
\hline 6 & 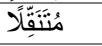 & mutanaqqilan & Mutanaqqilan \\
\hline
\end{tabular}


Respondent 3 also has been influenced by Malay dialect which is the Terengganuian dialect, as shown in Table 3. The words that have the letter ' $n$ ' at the back are mistakenly pronounced by adding the sound of $/ \mathrm{y} /$ after it. This phenomenon suggests that first language is really giving a difficulty towards second language learners.

Table 4. Transcription of Respondent 4's pronunciation

\begin{tabular}{|c|c|c|c|}
\hline Bil & Words & Transliteration & $\begin{array}{c}\text { Respondent } \\
4\end{array}$ \\
\hline 1 & قَفُبُوْرِ & Qubūri & Kubūri \\
\hline 2 & مَحْظُوْرِ & mahzūrin & Mahzūri \\
\hline 3 & الصََّاِةٍ & as-s $\underline{\text { salāti }}$ & aś-śsalā \\
\hline 4 & عَوْرَةٌ & 'auratun & 'aurat \\
\hline 5 & رِجَالٍٍ & rijālin & Rijālin \\
\hline 6 & مُنَقَقِّلَا & mutanaqqilan & Mutanaqqila \\
\hline
\end{tabular}

Table 4 shows no more mistakes in terms of the letter ' $\mathrm{g}$ ', but Respondent 4 pronounced the Arabic words as Malay pronunciation. For example, the Arabic word 'auratun' was pronounced by Malays as 'aurat'. That is why the respondent has mistakenly pronounced it as 'aurat'. Besides that, the word "qubūri" was pronounced like a Malay sound, as 'kubūri'. Meanwhile, the words 'mahzūrin' and 'as-salāti' were pronounced without the sound of certain letters at the end.

Table 5. Transcription of Respondent 5's pronunciation

\begin{tabular}{|c|c|c|c|}
\hline Bil & Words & Transliteration & Respondent 5 \\
\hline 1 & 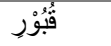 & qubūri & qubūri \\
\hline 2 & مَحْظوْرٍ & mahzūrin & Mahzūring \\
\hline 3 & الصنَّلَةِ & aś-salāti & as-salāt \\
\hline 4 & عَوْرَةٌ & 'auratun & 'auratun \\
\hline 5 & رِجَالٍ & rijālin & Rijāling \\
\hline 6 & مُنَنَقِلًَ & mutanaqqilan & Mutanaqqilang \\
\hline
\end{tabular}

In Table 5, the result shows that the respondent has more mistakes in terms of the letter ' $\mathrm{g}$ '. There are three words that have been pronounced by adding the letter ' $\mathrm{g}$ '. For example, the Arabic word 'mutanaqqilan' was pronounced as 'mutanaqqilang', the word 'rijālin' was pronounced as 'rijāling' and the word 'mahzūrin' was pronounced as 'mahzūring'.

\subsection{Discussion}

As a result, research questions can be answered correctly with the supporting evidence. There are several aspects that influenced the second language. One of them is the sound of $/ \mathrm{y} /$. Noor Rohana Mansor, Noraien Mansor, and Normaliza Abd Rahim (2013) in their research stated that "consonant sound of the word that ends with the letter ' $\mathrm{n}$ ' as [n] dental nasal consonants of speech, has been replaced with a combined consonant word ending with 'ng' namely as [ ${ }^{\mathrm{p}}$ ] soft palate nasal consonant expression". It has been used by the respondents without conscious thought.

The other aspect is the sounds that have not been used in Malay words such as the letter ' $\mathrm{'}$ ' in Arabic is pronounced as 'za', a bit thicker than the usual 'za'. The letter ' $\tau$ ' is pronounced as 'ha' which is using gullet cavity or epiglottis. Both organs are used to test for sounds of $[\varepsilon][\tau][\dot{\tau}][\dot{\varepsilon}]$ [ق] (Nik Mohd Rahimi, Harun Baharudin, Ghazali Yusri, Kamarul Shukri Mat Teh dan Mohamed Amin Embi (2010)).

Compared to a research done by Issraq Ramli (2004), the Sabahan dialect which is used in a state in the east of Malaysia also has similar effects towards Arabic pronunciation in terms of the sounds that are not used in Arabic pronunciation. In other words, the first-language influence has its impact on the Arabic phonemes as some phonemes are not available in the Sabahan dialect.

In conclusion, Arabic pronunciation is definitely influenced by the Terengganuian dialect among Terengganuians. Hence, the learners must overcome these challenges to do better in learning the Arabic Language.

\section{Conclusion}

Overall, the influence of native languages does exist among students who learn Arabic especially for those who communicate using only the Malay language. This is because their tongues have been synonymous with the terms of that language. In fact, learning Arabic language is increasingly difficult as they grow older due to frequent conversations with members of the first language. Therefore, those who want to master the Arabic language, especially 
in communicative skills must concentrate on the references that are affected by their dialect and must try to isolate it from the Arabic pronunciation of consonants or words.

Further studies should be carried out by taking into account the study that the participants are involved in and more detailed research methods. The combination of qualitative and quantitative approaches are recommended, namely qualitative approach that involves a larger number of participants and varying demographics, and also the quantitative approach by using questionnaires' self-assessment 'on the ability and confidence towards the influence of respondents' native language / dialect of Arabic language, especially for verbal skills.

\section{Acknowledgments}

This work was supported in part by IRMI-UiTM under Grant No. 600-IRMI/DANA 5/3/ARAS (0015/2016).

\section{References}

Abdul Hamid Ahmad (1988). Pengaruh Bahasa Sungai dalam Pengajaran dan Pembelajaran Bahasa Malaysia Baku. Penulisan Ilmiah Bacelor Pendidikan (PBMP), Universiti Pertanian Malaysia, Serdang.

Abdul Qadir Leong. (2003). Tajwid Al-Quran Rasm Uthmani. Kuala Lumpur :Pustaka Salam Sdn. Bhd.

Ashinida Aladdin. (2012). Analisis Penggunaan Strategi Komunikasi dalam Komunikasi Lisan Bahasa Arab. GEMAOnline ${ }^{\circledR}$ Journal of Language Studies. 12(2), 645-666.

Azman Che Mat \& Ahmad Nazuki@ Marzuki Yaakob (2010). Kegunaan Transliterasi Dalam Pengajaran Dan Pembelajaran Bahasa Arab. GEMA Online Journal of Language Studies, 10(2), 19-35.

Issraq Ramli (2004) Pengaruh Unsur Fonologi Dialek Melayu Sabah dalam sebutan bahasa Arab. Master Thesis, University of Malaya.

Kamarulzaman Abd. Ghani \& Nik Mohd Rahimi. (2000). Pengaruh bahasa Melayu ke atas sebutan bahasa Arab dan kemahiran tilawah al-Quran. Jurnal Sari, 18, 67-79.

Nik Mohd Rahimi, Harun Baharudin, Ghazali Yusri, Kamarul Shukri Mat Teh dan Mohamed Amin Embi,(2010). Pembelajaran Konsonan Arab Mengikut Pelat Bahasa Melayu. GEMA Online Journal of Language Studies, 10(3), 1-14.

Noor Rohana Mansor, Noraien Mansor, and Normaliza Abd Rahim,(2013). Dialek Melayu Terengganu: Pendokumentasian dan pengekalan warisan variasi bahasa tempatan. Jurnal Melayu, 10 . pp. 21-35. ISSN 1675-7513

S.O. Labo-Popoola. (2010). The Place of Literature in the Teaching of English Language as a Second Language. The Social Sciences, 5: 49-54.

Suthanthiradevi A/P J.N.J.Money. (1996). Pengaruh Bahasa Ibunda Dalam Proses Pembelajaran Bahasa Melayu MuridMurid India. Sarjana Sains. Jabatan Pengajian Melayu.

\section{APPENDIX}

\begin{tabular}{|c|c|c|c|}
\hline $\begin{array}{c}\text { Arabic } \\
\text { Character }\end{array}$ & Transliteration & & \\
\hline$\varepsilon$ & , & $\dot{\varepsilon}$ & $\mathrm{gh}$ \\
\hline ب & $\mathrm{b}$ & ف & $\mathrm{f}$ \\
\hline$ت$ & $\mathrm{t}$ & ق & $q$ \\
\hline$\dot{H}$ & th & 5 & $\mathrm{k}$ \\
\hline ج & $\overline{\mathrm{j}}$ & $J$ & 1 \\
\hline$\tau$ & $\mathrm{h}$ & 5 & $\mathrm{~m}$ \\
\hline$\dot{\tau}$ & $\mathrm{kh}$ & $\dot{ن}$ & $\mathrm{n}$ \\
\hline د & $\mathrm{d}$ & ه & $\mathrm{h}$ \\
\hline$\dot{j}$ & $\underline{\mathrm{dh}}$ & $و$ (consonant) & $\mathrm{W}$ \\
\hline$\jmath$ & $\mathrm{r}$ & ي (consonant) & $\mathrm{y}$ \\
\hline$j$ & $\mathrm{Z}$ & $\ddot{0}$ & $\underline{\mathrm{tt}}$ \\
\hline س & $\mathrm{S}$ & I (vowel) & $\bar{a}$ \\
\hline ش & $\underline{\mathrm{sh}}$ & g(vowel) & $\overline{\mathrm{u}}$ \\
\hline ص & $\underline{\mathbf{S}}$ & ي (vowel) & $\overline{1}$ \\
\hline ض & $\underline{\mathrm{d}}$ & e & $\mathrm{u}$ \\
\hline b & $\underline{t}$ & 6 & $\mathrm{a}$ \\
\hline ظ & $\underline{Z}$ & ? & $\mathrm{i}$ \\
\hline$\varepsilon$ & 6 & & \\
\hline
\end{tabular}

*referred to: Text Book of TAC101, Al-Munir, UiTM. 